\title{
POTENCJAŁY I STREFY PROBLEMOWE W ZAKRESIE ŚWIADCZENIA USŁUG PUBLICZNYCH NA OBSZARACH WIEJSKICH W SKALI REGIONALNEJ
}

\section{POTENTIALS AND PROBLEM AREAS IN THE PROVISION OF PUBLIC SERVICES IN RURAL AREAS AT REGIONAL SCALE}

\author{
Krystian HEFFNER $^{1} \bullet$ Brygida KLEMENS $^{2}$ \\ ${ }^{1}$ Uniwersytet Ekonomiczny w Katowicach \\ Katedra Gospodarki Przestrzennej i Środowiskowej \\ ul. Bogucicka 14, 40-287 Katowice \\ heffner@ue.katowice.pl \\ ${ }^{2}$ Politechnika Opolska \\ Wydział Ekonomii i Zarządzania, Katedra Polityki Regionalnej \\ ul. Prószkowska 76, 45-785 Opole \\ b.klemens@po.opole.pl
}

\begin{abstract}
Zarys treści: W artykule wskazano przykładowe badania dotyczące dostępności i jakości usług publicznych. Omówiono kategorie i przykłady usług publicznych, odnosząc je zwłaszcza do poziomu lokalnego (w szczególności na obszarach wiejskich). Skupiono się głównie na usługach o charakterze społecznym, administracyjnym i technicznym. Omówiono skutki niskiego poziomu ich świadczenia na obszarach wiejskich oraz znaczenie podnoszenia ich jakości. Podstawą przeprowadzonej analizy były jakościowe i ilościowe dane zebrane na obszarach wiejskich województwa opolskiego.
\end{abstract}

Słowa kluczowe: usługi publiczne, dostęp do usług publicznych, obszary wiejskie.

\section{Wprowadzenie}

Artykuł dotyczy przestrzennego zróżnicowania form świadczenia usług publicznych oraz ich dostępności na obszarach wiejskich województwa opolskiego. Podjęto próbę zidentyfikowania miejsc i stref z potencjałami oraz wskazano obszary problemowe (strefy deficytów) w tym zakresie. Analizę przeprowadzono w oparciu o materiały statystyczne i kartograficzne dotyczące lokalnych i ponadlokalnych jednostek terytorialnych (gminy i powiaty), charakteryzujące wymiar ilościowy i rozkład przestrzenny struktur związanych z usługami publicznymi oraz ich dostępność dla mieszkańców wsi i użytkowników z poziomu lokalnego i ponadlokalnego. Umożliwiło to wyznaczenie stref, w których występu- 
ją problemy w tym zakresie i można rozważyć rodzaj i sposób interwencji poprawiającej sytuację.

Sprowadzenie wyników badania do ujęcia terytorialnego umożliwia wskazanie gmin, które tworzą w miarę zwarte obszary (obszary problemowe, strefy funkcjonalne), dla których rozwiązania, związane z dostępem do usług publicznych, mogą przyjąć jednorodny w sensie przestrzennym i organizacyjnym charakter. Utworzenie wykazu gmin (jednostek lokalnych), które dysponują potencjałami w zakresie usług publicznych dla wsi i analogicznego zestawu gmin charakteryzujących się zidentyfikowanymi problemami w tej sferze: brak dostępu lub słaby dostęp, niski poziom świadczenia usług, niedopasowana struktura świadczonych usług publicznych itd. (por. Wolf 2007, Szarfenberg 2010, OECD 2010, Kobylińska 2013). Ujęcie terytorialne jest niezbędne w procedurze określania poziomu i kierunków koncentracji środków z funduszy strukturalnych w regionach w perspektywie finansowej w latach 2014-2020 (por. m.in. Bedrunka 2011; Malik, Bedrunka 2015).

Wnioski i rekomendacje dla polityki rozwoju obszarów wiejskich regionu opolskiego koncentrują się na określeniu zapotrzebowania na usługi publiczne w różnych częściach regionu i wskazaniu ośrodków, gdzie mogą one być realizowane. Wiele wskazuje na to, że głównym problemem w sferze usług na obszarach wiejskich nie jest dostęp do usług, ale niezawodność ich świadczenia oraz stabilność miejsc, w których są świadczone.

Przedmiotem analizy były zweryfikowane merytorycznie w Departamencie Polityki Regionalnej i Przestrzennej Urzędu Marszałkowskiego Województwa Opolskiego (UMWO) wyniki badania ankietowego przeprowadzonego w organach samorządowych gmin i powiatów województwa opolskiego. Wypowiedzi ankietowanych, z jednej strony są opiniami eksperckimi (respondenci znają sytuację w jednostkach terytorialnych, którymi zarządzają), z drugiej nie ulega wątpliwości, że mają charakter subiektywny i w związku z tym trudno porównywalny (opinie, ze względu na formę badania, formułowane były w skali liczbowej od-3 przez 0 do +3 , co łącznie daje siedem klas bonitacyjnych, ale bez wskazanych stanów odniesienia). Ostrożnie należy również podchodzić do porównań i wnioskowań o charakterze hierarchicznym - a więc do sformułowanych przez respondentów opinii i ocen dotyczących tych samych kwestii, ale wyrażanych z poziomu lokalnego (gminy) i ponadlokalnego (powiaty).

\section{Usługi publiczne na wsi i dla obszarów wiejskich}

Zarówno w ujęciach teoretycznych, jak i praktyce polityki rozwoju, usługi publiczne rozumiane są zwykle bardzo szeroko, m.in. jako aktywność ze strony sfery publicznej i samorządowej, która powiązana jest z pojęciem zgody społecznej, uznając że pewne usługi przysługują wszystkim obywatelom bez względu na dochód (Hnatyszyn-Dzikowska i PoIcyn 2015). W tym rozumieniu znaczenie ma także kwestia finansowania takich usług, które może pochodzić w całości lub w części ze środków publicznych, ich dostępność może być całościowo lub częściowo odpłatna bądź bezpłatna, mogą być dostarczane bezpośrednio lub pośrednio przez podmioty prywatne zapewniające daną usługę i finansowane ze środków publicznych (por. Sołtys 2013, s. 3).

Wprawdzie w opracowaniach dotyczących usług publicznych grupuje się je w różny sposób (tab. 1), ale najczęściej wyróżnia się od dwóch do pięciu grup i kilkanaście kategorii tego typu usług (zob. m.in. Wańkowicz 2004). 
Tabela 1. Klasyfikacja usług publicznych wg różnych kryteriów

\begin{tabular}{|c|c|}
\hline $\begin{array}{l}\text { Kryteria kla- } \\
\text { syfikacji usług } \\
\text { publicznych }\end{array}$ & Rodzaje usług publicznych \\
\hline $\begin{array}{l}\text { Związek } \\
\text { z gospodarką }\end{array}$ & $\begin{array}{l}\text { Gospodarcze: } \\
\text { - powiązane z produkcją (nauka i rozwój techniki, transport i łączność, handel, finanse, } \\
\text { - zbezpieczenia) } \\
\text { - } \text { nych potrane z kształtowaniem osobowości ludzkiej, zaspokajaniem duchowych i psychofizycz- } \\
\text { - związane z kształtowaniem materialnych warunków bytu (gospodarka mieszkaniowa, ko- } \\
\quad \text { munalna, usługi bytowe na rzecz gospodarstwa domowego oraz usługi osobiste i domowe) } \\
\text { Pozagospodarcze: } \\
\text { - aparat władzy i porządku publicznego } \\
\text { - administracja rządowa i samorządowa } \\
\text { - obrona narodowa } \\
\text { - organizacje polityczne } \\
\text { - instytucje wymiaru sprawiedliwości } \\
\text { - organizacje oraz zrzeszenia społeczne i wyznaniowe }\end{array}$ \\
\hline $\begin{array}{l}\text { Cele działalności } \\
\text { usługowej }\end{array}$ & $\begin{array}{l}\text { Produkcyjne (np. roboty instalacyjne, montażowe, dystrybucja energii elektrycznej) } \\
\text { Konsumpcyjne (np., usługi transportowe, komunalne, mieszkaniowe, ochrona zdrowia, } \\
\text { opieka społeczna) } \\
\text { Ogólnospołeczne }\end{array}$ \\
\hline $\begin{array}{l}\text { Rodzaj wyniku } \\
\text { pracy }\end{array}$ & $\begin{array}{l}\text { Renowacyjne (mające na celu zachowanie lub przywracanie wartości użytkowej dóbr) } \\
\text { Dystrybucyjne (odnawianie lub zwiększanie drogą wymiany wartości zasobów rzeczowych) } \\
\text { Rekreacyjne (polegające na oddziaływaniu na właściwości fizjologiczne człowieka, np. usługi } \\
\text { lecznicze, turystyczne, wypoczynkowe) } \\
\text { Oświatowo-kulturalne (przekazywanie wiedzy i doznań artystycznych) } \\
\text { Organizacyjne (podejmowanie i przekazywanie decyzji osobom lub grupom osób) }\end{array}$ \\
\hline Odpłatność & $\begin{array}{l}\text { Rynkowe (będące przedmiotem kupna-sprzedaży, posiadające określoną cenę) } \\
\text { Pozarynkowe (przekazywane na zasadach nieodpłatnych lub częściowej odpłatności } \\
\text { np. oświata, kultura, opieka zdrowotna) }\end{array}$ \\
\hline Forma prawna & $\begin{array}{l}\text { Świadczone przez przedsiębiorstwa prywatne } \\
\text { Oferowane przez przedsiębiorstwa publiczne (np. telewizja publiczna) } \\
\text { Oferowane przez instytucje publiczne i samorządowe oraz organizacje i stowarzyszenia }\end{array}$ \\
\hline $\begin{array}{l}\text { Wańkowicz } \\
\text { 2004, Kożuch, } \\
\text { Kożuch } 2011\end{array}$ & $\begin{array}{l}\text { Administracyjne (obejmują zadania realizowane przez administrację publiczną, związane } \\
\text { z dokonywaniem czynności administracyjnych): } \\
\text { - wydawanie dokumentów nie będących decyzjami administracyjnymi, zezwoleniami, } \\
\text { - koncesjami } \\
\text { - wprowadzanie do baz danych uzyskiwanych bezpośrednio od klientów } \\
\text { - wdministracyjnego } \\
\text { - wydawanie zezwoleń i koncesji dotyczących działalności gospodarczej reglamentowanej } \\
\text { Publiczne o charakterze społecznym: } \\
\text { - ochrona zdrowia } \\
\text { - oświata i wychowanie } \\
\text { - kultura } \\
\text { - kultura fizyczna, wypoczynek i rekreacja } \\
\text { - pomoc i opieka społeczna } \\
\text { - mieszkalnictwo } \\
\text { - bezpieczeństwo publiczne } \\
\text { Publiczne o charakterze technicznym: } \\
\text { - transport publiczny } \\
\text { - infrastruktura transportu i komunikacji } \\
\text { - zaopatrzenie w wodę i kanalizacja, oczyszczanie ścieków } \\
\text { - gospodarka odpadami oraz utrzymanie czystości i porządku } \\
\text { - cmentarnictwo } \\
\text { - zaopatrzenie w energię (elektroenergetyka, gazownictwo, ciepłownictwo) } \\
\text { - zieleń publiczna }\end{array}$ \\
\hline
\end{tabular}

Źródło: Z. Strzelecki i in. (2013), W. Wańkowicz (2004) zmienione. 
W badaniu analizowano opracowanie materiałowe UMWO, w którym wyniki i treść ankiet zestawiono w dwóch częściach - Infrastruktura i środowisko oraz Społeczeństwo i sprawy społeczne, co tylko częściowo odpowiada standardowym klasyfikacjom usług publicznych.

Za względu na zróżnicowanie zadań realizowanych przez jednostki samorządu terytorialnego w układzie hierarchicznym (gminy, powiaty i województwa), te same grupy usług można zaklasyfikować do różnych kategorii, przy czym na poziomie lokalnym chodzi zwykle o najbardziej podstawowy zakres świadczenia i dostępu do usług (np. lecznictwo otwarte), na poziomie ponadlokalnym są to usługi wyższego rzędu (np. szkolnictwo średnie), a na poziomie regionalnym dotyczą one funkcjonowania społeczności i użytkowników całego regionu (np. drogi wojewódzkie).

Jeśli rozważać świadczenie i dostęp do usług publicznych na najniższym, bezpośrednim poziomie kontaktu z nimi na obszarach wiejskich, a więc w sferze lokalnej, to wielu autorów skłania się do ich podziału na trzy grupy (zob. m.in. Borowiec 2007, s. 43-44; Bińczycki 2010, s. 22-23; Heffner i Gibas 2013, s. 13-14):

- usługi administracyjne, które obejmują różne formy obsługi formalno-prawnej i dokumentacyjnej (m.in. wydawanie potwierdzeń i dokumentów na życzenie klienta, niezbędnych decyzji administracyjnych (ochrona środowiska, gospodarka przestrzenna, budownictwo), zezwoleń, koncesji, pobieranie informacji, rejestracja (np. urodzenia, śluby, rozwody, zgony), itd.;

- usługi o charakterze społecznym, związane z m.in. ochroną zdrowia (profilaktyka i lecznictwo), oświatą i wychowaniem (biblioteki, czytelnie, żłobki), edukacją (przedszkola, szkoły podstawowe i gimnazja), kulturą (teatry, ośrodki kultury, filharmonie), kulturą fizyczną i rekreacją, pomocą i opiekę społeczną (noclegownie, domy dziennego pobytu), mieszkalnictwem oraz bezpieczeństwem publicznym;

- usługi o charakterze technicznym, wśród których wskazuje się m.in. usługi transportu zbiorowego, infrastrukturę obsługi transportu i sieci transportowe, gospodarkę wodną, odprowadzanie i utylizacja ścieków (kanalizacja i oczyszczalnie), gospodarkę odpadami, cmentarnictwo, zaopatrzenie w energię (elektroenergetyka, gazownictwo, ciepłownictwo).

Zakresy świadczenia usług publicznych na poziomie lokalnym i ponadlokalnym są często analogiczne, ale różnią się dostępnością do wyspecjalizowanych form lub poziomów decyzyjnych. Dotyczy to głównie usług administracyjnych i społecznych - np. ochrona zdrowia, (lecznictwo otwarte, zamknięte), oświata i wychowanie, edukacja (poziom podstawowy, średni, wyższy, zawodowy), pomoc i opieka społeczna. W obszarze usług publicznych o charakterze technicznym znaczenie mają formy organizacyjne i sposób ich funkcjonowania (np. dostęp do transportu publicznego), hierarchia i rodzaj obsługi (np. odśnieżanie dróg, reakcja na awarie itd.; Heffner i Gibas 2013, s. 14).

Na poziomie lokalnym, a więc m.in. na obszarach wiejskich dostarczaniem usług publicznych zajmuje się przede wszystkim samorząd lokalny (gminny), w mniejszym stopniu ponadlokalny (powiatowy) i w niektórych zakresach również regionalny. Łącznie zaspokajają one zbiorowe potrzeby społeczności wiejskich funkcjonujących w zasięgu formalnego działania struktur samorządowych różnych poziomów. Działanie administracji publicznej skutkuje również licznymi usługami administracyjnymi o charakterze formalno-prawnym (pozwolenia, koncesje, potwierdzenia itd., por. Kobylińska 2013 s. 131-140).

Liczne usługi publiczne obejmujące użytkowników wiejskich są realizowane na szczeblu regionalnym - chodzi zarówno o usługi administracyjne, jak i usługi publiczne o cha- 
rakterze społecznym oraz usługi publiczne o charakterze technicznym. Są to z reguły aktywności bądź działalności albo możliwości dostępu do nich zlokalizowane punktowo lub liniowo tylko w nielicznych miejscach w regionie (np. szpitale kliniczne, wyspecjalizowane przychodnie lekarskie, biura obsługi administracyjnej i prawnej, autostrady, linie kolejowe itd.). Wymusza to określone formy kontaktu i powiązań wynikające z bardzo selektywnej dostępności do tego typu usług publicznych, co uwypukla znaczenie transportu i komunikacji oraz organizacji systemu umożliwiającego dostęp i korzystanie z usług świadczonych na regionalnym i krajowym poziomie (Heffner i Gibas 2015, s. 20-23).

Badanie i analizowanie dostępności usług, w tym zwłaszcza usług publicznych, jest ważnym elementem oceny poziomu rozwoju społeczno-gospodarczego jednostek terytorialnych oraz jakości życia ich mieszkańców (por. np. Flejterski i in. 2005; Dominiak 2009). W analizowanych wynikach badań ankietowych, w których identyfikowano potencjały i problemy rozwoju społeczno-gospodarczego województwa opolskiego w ujęciu terytorialnym (rejony i miejsca lepszej lub gorszej dostępności usług publicznych, strefy niedopasowania, obszary "nadwyżek” i „niedoborów”, wystarczająca i niewystarczająca intensywność świadczenia usług itd.) odniesiono się do wielu z powyższych kwestii. Formułowane oceny stanu dotyczyły przede wszystkim poziomu lokalnego (gminy), który dla społeczności wiejskich ma kluczowe znaczenie. Wybór usług publicznych na obszarach wiejskich - dokonany w oparciu o kwerendę literaturową - obejmuje te zagadnienia, które są najistotniejsze dla funkcjonowania mieszkańców wsi ${ }^{1}$.

Wprawdzie w literaturze omawia się również inne rodzaje usług publicznych, nie mają one jednak priorytetowego znaczenia (np. utrzymanie zieleni publicznej) dla oceny dostępności świadczonych usług. Jakkolwiek uwzględniono je w analizowanym zestawieniu UMWO, to nie były istotne dla oszacowania dostępności usług publicznych na obszarach wiejskich województwa opolskiego.

Obszary wiejskie w polityce rozwoju społeczno-gospodarczego są zazwyczaj traktowane jako strefy słabszego rozwoju, stagnacji, a nawet depresji, często z dużymi problemami społecznymi i gospodarczymi (m.in. depopulacją, migracjami, brakiem aktywności, bezrobociem czy starzeniem się ludności, niedoinwestowaniem, niedoborami kapitałowymi itd.). Jako jeden ze sposobów poprawy tej sytuacji wskazuje się możliwość polepszenia dostępności i poprawy jakości świadczenia usług publicznych (Shergold i Parkhurst 2010; Klemens 2013, s. 151; PROW 2014). Spośród badanych kwestii, dotyczących zaspokojenia potrzeb mieszkańców wsi, jako wiodące wskazuje się większość usług o charakterze technicznym (transportowo-komunikacyjne, komunalne - dostęp m.in. do wodociągu, kanalizacji, gazu, zbiorczego ogrzewania itp.). Wśród usług publicznych o charakterze społecznym priorytetowe znaczenie mają usługi edukacyjne, zarówno przedszkolne jak i szkolne, dostęp do służby zdrowia i opieki nad dziećmi (złłobki). W dobie tzw. silver economy coraz istotniejszą rolę odgrywa także dostęp do usług związanych z opieką nad ludźmi starszymi. Wśród ważnych możliwości dla mieszkańców wsi wymienia się również dostępność usług związanych z kulturą, kulturą fizyczną, wypoczynkiem i rekreacją. Nie pomija się również dostępu do usług administracyjnych, chociaż częstotliwość występujących zapotrzebowań na ich świadczenie jest znacząco niższa.

${ }^{1}$ Autorzy publikacji dokonywali już przeglądu badań i literatury we wskazanej sferze funkcjonowania usług publicznych i czynników warunkujących dostęp do nich: zob. m.in. K. Heffner i B. Klemens (2012, s. 81-88; 2013, s. 90-101; 2015, s. 51-70) oraz B. Klemens (2013, s. 151-163).. 
Relatywne pogarszanie się warunków życia ludności wiejskiej jest często (subiektywnie) wiązane z odczuwanym, niskim poziomem dostępności i niezadowalającą jakością świadczenia usług publicznych. Jest to jeden z składników stopniowego wchodzenia niektórych stref wiejskich w spiralę pogarszających się warunków rozwojowych. Efektem tych procesów jest postępujący spadek zaludnienia coraz szerszych stref wiejskich i ich nasilająca się peryferyzacja (Heffner 2010, s. 163-184; Heffner 2011b, s. 49-72). Do działań związanych z polityką rozwoju, odwracających te negatywne trendy, niewątpliwie można zaliczyć inicjatywy organizacyjne, przekształcenia i inwestycje poprawiające dostępność do ważnych dla mieszkańców wsi usług publicznych. Chodzi m.in. o tworzenie możliwości bezpośredniego korzystania z nich na wsi lub w pobliskich lokalnych ośrodkach (małe miasta) oraz reorganizacje i działania służące „przybliżaniu” miejsc świadczenia usług ludności wiejskiej (m.in. usługi edukacyjne, medyczne, zdrowia i opieki społecznej, kultury, rekreacyjne, administracyjne). Priorytetowe znaczenie ma zwiększanie efektywności dostarczania usług publicznych na obszary wiejskie oraz o ich szerokie udostępnianie i wysoka jakość. Może się to odbywać poprzez zmiany organizacji i formy ich świadczenia (m.in. zlecanie podmiotom niepublicznym, jest to jednak kwestia rozwiązań ustawowych wykraczających poza politykę rozwoju regionu) oraz wdrożenie e-usług (Polska 2030...).

Szczególnie jednak obszary wiejskie określane jako słabiej rozwinięte, wymagają podjęcia działań służących poprawie dostępności, niezawodności i jakości świadczenia usług publicznych. Inicjatywy w sferze publicznej mogą być jednym z istotnych czynników powstrzymujących odpływ migracyjny z wielu stref wiejskich, szczególnie tych z „syndromem narastającej peryferyjności". Odwrotnie, brak działań w tym kierunku może uruchomić i zintensyfikować procesy odpływu ludności wiejskiej, szczególnie tej aktywnej i młodej, co skutkuje zmniejszeniem popytu na lokalnie sytuowane usługi publiczne i niedoborami środków do ich utrzymywania, nie mówiąc o poprawie dostępu czy jakości ich świadczenia. W efekcie spada odczuwalna jakość życia mieszkańców wsi i wzmagają się procesy dalszego odpływu do większych miast i za granicę. Uprawnione jest więc stwierdzenie, że jednym z głównych celów polityki rozwoju regionalnego (poziom krajowy) i polityk rozwoju prowadzonych przez regiony, powinno być niedopuszczenie do uruchomienia procesu degradacji obszarów wiejskich w strefach zagrożonych peryferyzacją (Heffner i Gibas 2013, s. 16).

W wewnętrznych układach regionów, głównie w strefach wiejskich o cechach peryferii, w tym również w województwie opolskim, ujawniają się tendencje do utrwalania trendów spowolnienia rozwoju i negatywnych charakterystyk poziomu rozwoju społeczno-gospodarczego. Strefa takich pogłębiających się, negatywnych zjawisk rozwojowych na obszarach wiejskich stopniowo ukształtowała się we wschodniej części regionu opolskiego, obejmując powiaty: oleski, strzelecki, kędzierzyńsko-kozielski i głubczycki. Jest to zwykle łączny skutek permanentnego odpływu migracyjnego i stopniowego pogarszania się dostępności i jakości w zakresie szeroko rozumianych usług publicznych (Heffner 2011a, s. 9-34). 


\section{Wybrane badania jakości i dostępu do usług publicznych}

W rozważaniach dotyczących usług publicznych podkreśla się wagę ich dobrej dostępności ${ }^{2}$, zarówno w ujęciu tradycyjnym (np. wizyta w urzędzie), jak również usług elektronicznych (np. e-zdrowie, e-edukacja, e-administracja). Jednak, chodzi głównie o dostępność usług administracyjnych, na znaczenie dostępu do usług komunalnych czy społecznych zwraca się mniej uwagi. Generalnie, badania pokazują, że dla odbiorców i konsumentów usług publicznych istotne jest podnoszenie jakości usług i ten aspekt staje się stopniowo niezbędnym elementem zmian i standardów funkcjonowania w administracji publicznej. Większą wagę przykłada się do jakości dostarczanych usług publicznych w administracji centralnej, ale coraz częściej założenia te transponowane są na poziom najbliższy obywatelom, a więc lokalny (Wańkowicz 2004). Kolejnym czynnikiem, którego rola znacząco wzrasta jest orientacja na stały wzrost efektywności usług publicznych świadczonych na poziomie JST, zwłaszcza w trudnej sytuacji finansów publicznych i stale rosnących oczekiwań wspólnot samorządowych (Kachniarz 2012, s. 7-9; Barczyk i in. 2013).

Wprawdzie badania nad usługami publicznymi i ich dostępnością nie mają w Polsce długiej historii, to ich intensywność i zakres wyjaśniania wzrasta. Jednym z pierwszych był projekt prowadzony w Gdańsku w 1996 r. Gdańsk - niektóre aspekty życia miasta (Drozd-Wiśniewska i Woźniak 2011, s. 45-63). Oceniono w nim percepcję wybranych sfer życia, koncentrując się na zmianach w ich jakości (poprawa, pogorszanie się lub brak zmian w sytuacji). Od roku 2007 w sposób cykliczny przeprowadzane jest badanie dotyczące oceny jakości życia w Gdańsku (próba reprezentatywna dorosłych mieszkańców). W 1999 r. Związek Miast Polskich na potrzeby realizowanego projektu monitorowania usług publicznych dokonał analizy porównawczej w czterech obszarach: kultury, ochrony zdrowia, pomocy społecznej oraz transportu (Monitorowanie usług publicznych...). W sferze kultury badano m.in. kwestie dotyczące wydatków na preferowane dziedziny usług, dofinansowywanie podmiotów prywatnych, publicznych i sektora pozarządowego oraz uczestnictwo w kulturze. W obszarze ochrony zdrowia badano stan środowiska naturalnego (powierzchnie zielone, skażenia powietrza i wody), stan zdrowia mieszkańców (umieralność i zachorowalność), potencjał i działalność służby zdrowia. Pomoc społeczna analizowana była pod kątem potrzeb osób ubogich, bezdomnych, opieki stacjonarnej i półstacjonarnej, usług opiekuńczych. Warunki funkcjonowania transportu miejskiego analizowano pod względem jakości układu drogowego (dróg i ulic), transportu indywidualnego, wypadków drogowych, zbiorowej komunikacji pasażerskiej.

Z początkiem XXI wieku stosunkowo często analizowano i rozważano problem dostępu i jakości usług publicznych. Jako jeden z pierwszych uważa się Program Rozwoju Instytucjonalnego (PRI) i podejmowane w jego ramach prace badawcze prowadzone m.in. przez Instytut Badań nad Gospodarką Rynkową (Duda i in. 2004 za: Kachniarz 2007) i Małopolską Szkołę Administracji Publicznej (Zawicki i Mazur 2004 za: Kachniarz 2007). PRI realizowany był w MSWiA w latach 2001-2004, a jego celem była poprawa działania urzędów samo-

\footnotetext{
2 Definicja dostępności w odniesieniu do usług publicznych była już przez autorów formułowana. Dostępność rozumiana jest jako możliwość skorzystania z usługi w racjonalnym czasie, co wiąże się istotnie z aspektem przestrzennym, np. dobra jakość połączeń komunikacyjnych, dogodna infrastruktura typu miejsca parkingowe, ulokowanie usługi w miejscu łatwo osiągalnym dla mieszkańców wsi (np. w centrum miejscowości) - zob. K. Heffner i B. Klemens (2015, s. 53). Dostępność może być również rozumiana w wymiarze ekonomicznym jako koszt do poniesienia (koszt nabycia usługi) oraz społecznym jako niewykluczanie grup społecznych z możliwości skorzystania z usługi - zob. Z Strzelecki i in. (2013, s. 5).
} 
rządowych dzięki aktualizacji i wdrożenia tej metody, która jest narzędziem samooceny stanu zarządzania jednostką samorządu i pozwala na łatwe zaprogramowanie działań doskonalących (www.pri.msap.pl dostęp 01.06.2016). W ramach projektu opracowano metodologię pomiaru i oceny usługi, która zapisana została w prostej formie tabelarycznej i zawierała sześć podstawowych części: charakterystyki usługi, opisu wskaźników, trzech części opisujących metodę pomiaru (wydajności, skuteczności i dostępności) oraz części opisującej sposób wnioskowania. Niestety, projekt ten nie przyniósł zakładanych efektów, co wynikało ze zmian prawnych i brak zachęt do stosowania metody (Wańkowicz 2004).

W latach 2005-2008 Ministerstwo Administracji i Cyfryzacji realizowało projekt ePUAP-Elektroniczna Platforma Usług Administracji Publicznej ${ }^{3}$. Efektem tego przedsięwzięcia jest działający portal ePUAP, służący do składania pism i wniosków oraz załatwiania spraw urzędowych drogą elektroniczną.

Podobny projekt realizowano w województwie opolskim, na poziomie lokalnym - eUrząd dla mieszkańca Opolszczyzny. Jego celem było zwiększenie dostępu do usług publicznych on-line oraz zmniejszenie dysproporcji w zakresie dostępu i wykorzystania internetu w codziennym życiu społeczno-gospodarczym mieszkańców województwa opolskiego. Jego efektem miał być łatwiejszy dostęp do usług publicznych, skrócenie czasu potrzebnego na obsłużenie klienta zewnętrznego, zmniejszenie liczby wizyt w urzędzie, wprowadzenie transparentności w funkcjonowaniu urzędu, obniżenie kosztów administracji ${ }^{4}$.

Obiecujący pod względem efektów jest projekt Budowanie potencjału instytucjonalnego samorzq̨dów dla lepszego dostarczania usług publicznych, który jest wspólną inicjatywą kilku organizacji: Związku Miast Polskich, Związku Powiatów Polskich i Związku Gmin Wiejskich RP, na którą zyskały one finansowanie z Europejskiego Obszaru Gospodarczego (Kachniarz 2007). Działaniami w tym projekcie były m.in. cykl doradczo-szkoleniowy dla kadry samorządowej (począwszy od 2007 r.) wraz z wymianą doświadczeń pomiędzy praktykami danej dziedziny (pracownikami samorządowymi). W latach 2011-2013 podjęto kolejny cykl szkoleń (na 45 jednostek samorządu terytorialnego udział wzięło 8 gmin wiejskich). Wśród celów projektu wymieniono podnoszenie jakości, efektywności i dostępności usług publicznych oraz monitorowanie strategii - z wykorzystaniem produktów i rezultatów projektu ${ }^{5}$.

Rozpoczęty w 2001 r. projekt PRI rozrósł się do kompleksowej Metody Planowania Rozwoju Instytucjonalnego, będącej przykładem holistycznego podejścia do doskonalenia jakości działań administracji publicznej, która doczekała się zmian w roku 2010, a w 2014 zostały zakończone prace nad jej aktualizacją (Bober 2015a, s. 9; Bober 2015b, s. 11). Zakres doskonalenia jakości obejmuje również usługi publiczne w podziale na kategorie usług: administracyjnych, społecznych i technicznych. Warto podkreślić, że zmiany w 2010 r. dokonane zostały obok współpracy ze Związkiem Miast Polskich i Związkiem Powiatów Polskich również ze Związkiem Gmin Wiejskich Rzeczpospolitej Polskiej.

Aktualnie (2016) Instytut Badań nad Gospodarką Rynkową realizuje projekt Wzorcowy System Regionalny Monitoringu Jakości Usług Publicznych i Jakości Życia (WSRMJUPiJŻ), którego istotą jest stworzenie zintegrowanego systemu mierzenia jakości usług publicznych i jakości życia, poprzez dostarczenie zarówno „twardych”, jak i „miękkich” narzędzi

\footnotetext{
3 http://mac.gov.pl/projekty/(dostęp 07.07.2012).

4 http://www.eurzad.wodip.opole.pl/portal/(dostęp 01.06.2016).

5 http://2011.jst.org.pl/uslugi/(dostęp 07.07.2012).
} 
monitoringu ${ }^{6}$. System podlega testowaniu w województwie pomorskim i w czterech gminach pilotażowych zlokalizowanych tym regionie: Gdańsku, Słupsku, Stegnie i Czarnej Wodzie (gminie miejsko-wiejskiej).

Przegląd badań dotyczących jakości i dostępności usług publicznych z pewnością nie jest kompletny. Poszczególne województwa prowadzą więc własne badania (zwłaszcza w kontekście dostępu do usług publicznych na obszarach wiejskich m.in. lubuskie, opolskie, mazowieckie, śląskie), jak również szereg ośrodków naukowych jest aktywnych w tym zakresie (zob. m.in. Dominiak 2007; Komornicki i in. 2009; Kuźnik 2013; Śleszyński 2014).

Wskazany przegląd badań uświadamia, że dostępność i jakość usług publicznych jest ważna zarówno z teoretycznego, jak i aplikacyjnego punktu widzenia. W przytoczonych przykładach analiz wykorzystywanych jest wiele metod i podejść badawczych różniących się istotnie od siebie, co utrudnia możliwość porównywania wyników badań, ale również wpływa na brak ich ciągłości (nie są wykonywane ani systematycznie ani kontynuacyjnie). Jest oczywiste, że oceny dostępności usług publicznych na obszarach wiejskich są fragmentaryczne i nie mają charakteru całościowego, bowiem zwykle przeprowadzane są sporadycznie i dotyczą tylko wybranych zagadnień (Michalska-Żyła 2016, s. 54), jakkolwiek zmiany w tym zakresie stopniowo stają się widoczne.

\section{Wnioski w zakresie dostępu do usług publicznych na obszarach wiejskich}

Na dostępność usług publicznych na obszarach wiejskich wpływ ma ulokowanie miejsc ich świadczenia w bezpośrednim sąsiedztwie potencjalnych usługobiorców oraz łatwość dotarcia do najbliższego ośrodka lokalnego (wsie gminne i małe miasta), ponadlokalnego (małe i średnie miasta) albo subregionalnego (miasta średnie) czy regionalnego (chodzi m.in. o część usług społecznych, administracyjnych), w którym te usługi są świadczone. Oznacza to, że dostępność transportowa i komunikacyjna jest kluczowa w tym aspekcie, świadczy przynajmniej pośrednio o jakości życia mieszkańców oraz wiąże się z poziomem peryferyjności obszarów wiejskich w sensie lokalnym, regionalnym i krajowym (por. Przygodzka 2010, s. 210-221)

Głównymi powodami odejścia od publicznego transportu na obszarach wiejskich i wykorzystywania przez mieszkańców wsi prywatnych samochodów jest brak dostępności do usług transportowych, brak bezpośrednich połączeń z ośrodkami świadczenia usług i miejscami pracy oraz inne niedogodności. Tylko dopasowane i niezawodne, wysokiej jakości usługi transportowe dostosowane do rzeczywistych wiejskich potrzeb, elastyczne, rozpropagowane i dobrze zintegrowane zapewniają ustabilizowany dostęp mieszkańców wsi społecznie defaworyzowanych do zewnętrznych rynków pracy, usług i możliwości rozwojowych. Jest to szczególnie istotne dla większości obszarów wiejskich, a szczególnie stref o cechach peryferyjności gospodarczej, społecznej i infrastrukturalno-przestrzennej (m.in. Heffner 2011a; Kamruzzaman i Hine 2011; Velaga i in. 2012; Heffner i Gibas 2013).

Dostępność większości usług publicznych, głównie o charakterze społecznym i administracyjnym, jest na obszarach wiejskich w zasadzie równa dostępności miejsc, w których te usługi są zlokalizowane (Szarfenberg 2010). Kwestią priorytetową pozostaje więc dobra

\footnotetext{
${ }^{6}$ http://monitoring.ibngr.pl/o-projekci/(dostęp 07.07.2016).
} 
jakość połączeń komunikacyjnych i drogowych z ośrodkami świadczącymi tego typu usługi. Zasadniczo chodzi o stałą i niezawodną dostępność w systemie usług komunikacyjnych (komunikacja zbiorowa) oraz w układzie sieci drogowej lub kolejowej - lokalnych centrów (większe wsie, wsie gminne, małe miasta) i centrów ponadlokalnych (miasta powiatowe, subregionalne i regionalne). Okazuje się, że dostęp do usług publicznych dla mieszkańców obszarów wiejskich jest utrudniony głównie ze względu na niestałość i niepewność połączeń komunikacyjnych (komunikacja zbiorowa), zwłaszcza wsi zlokalizowanych peryferyjnie w układzie lokalnym, regionalnym lub krajowym. Stosunkowo częste są przypadki potrójnie peryferyjnej (a więc skrajnie niekorzystnej) lokalizacji miejscowości wiejskich, a nawet całych gmin.

Istotne są więc rozwiązania lokalizacyjne (łatwość osiągnięcia miejsc świadczenia usług) oraz sprawność i stabilność obsługi komunikacyjno-transportowej na obszarach wiejskich, które w sposób trwały łączą miejscowości wiejskie z innymi wsiami i miastami (głównie siedzibami gmin), czy ośrodkami ponadlokalnymi i regionalnymi (w regionie opolskim - Opole, Kędzierzyn-Koźle, Nysa, Brzeg i Kluczbork).

Inną kwestią jest lokalizacja usług publicznych w przestrzeni miejskiej - jej niedogodność dodatkowo zmniejsza dostępność. Często usługi o charakterze publicznym dla mieszkańców wsi zlokalizowane są na peryferiach miasta, w trudno dostępnych komunikacyjnie miejscach. Wyższe koszty społeczne i dodatkowe utrudnienia dostępności sprzyjają społecznemu wykluczeniu mieszkańców wsi.

Usługi publiczne typu społecznego i administracyjnego powinny być łatwe do zlokalizowania i szybko dostępne, bez utrudnień w formach korzystania, a więc z dostępem do parkingów, dojazdem komunikacją miejską, koleją itp. Domyślną lokalizacją w przypadku tych usług powinny być centra miast i ośrodków wiejskich.

\section{Literatura}

Bedrunka K., 2011, Efektywne wdrażanie polityki spójności-doświadczenia dotychczasowych okresów programowania w województwie opolskim, a nowa wizja Polityki Spójności po 2013 roku, Barometr Regionalny, $\mathrm{nr} 4$ (26), s. 7-14.

Bober J. (red.), 2015a, Analiza instytucjonalna powiatu z ocenq realizacji standardów kontroli zarządczej. Metoda Planowania Rozwoju Instytucjonalnego, Uniwersytet Ekonomiczny w Krakowie, Kraków.

Bober J. (red.), 2015b, Analiza instytucjonalna gminy z ocenq realizacji standardów kontroli zarzq̨czej. Metoda Planowania Rozwoju Instytucjonalnego, Uniwersytet Ekonomiczny w Krakowie, Kraków.

Barczyk S., Baron M., Biniecki J., Kuźnik F., Ochojski A., Szczupak B., 2013, Efektywne świadczenie miejskich usług publicznych. Analiza - zarzqdzanie - polityka, Wydawnictwo Uniwersytetu Ekonomicznego w Katowicach, Katowice.

Bińczycki B., 2010, Urząd gminy jako organizator usług publicznych, [w:] A. Nalepka i A. Ujwar-Gil (red.), Organizacje komercyjne i niekomercyjne wobec wzmożonej konkurencji oraz wzrastających wymagań konsumentów, Wyższa Szkoła Biznesu-National Louis University, Warszawa, s. 21-27.

Borowiec L., 2007, Controlling w realizacji usług publicznych gminy, Oficyna WoltersKluwer Business, Kraków. 
Czarnecki A., 2005, Obszary wiejskie, urbanizacja wsi, rozwój wielofunkcyjny, rolnictwo wielofunkcyjne-przeglad pojęć, [w:] A. Rosner (red.), Uwarunkowania i kierunki przemian społeczno-gospodarczych na obszarach wiejskich, IRWiR PAN, Warszawa, s. 233-254.

Dominiak J., 2009, Dostępność usług publicznych na terenie województwa wielkopolskiego, Poznań, http://www.umww.pl/attachments/article/11578/1.Dost\%C4\%99pno\%C5\%9B\%C4\% 87\%20 us\%C5\%82ug\%20publicznych\%20na\%20terenie\%20wojew\%C3\%B3dztwa\%20wielkopolskiego. pdf

Drozd-Wiśniewska K., Woźniak W., 2011, Doświadczenia miasta Gdańsk w zakresie mierzenia jakości usług publicznych, [w:] Raport - krajowe i zagraniczne doświadczenia w zakresie badania jakości usług publicznych i jakości życia, Instytut Badań nad Gospodarką Rynkową, Gdańsk, s. $45-63$.

Duda J., Jeżowski A., Misiąg W., Nowak B., Szlachta J., Zaleski J., 2004, Mierzenie ilości i jakości usług publicznych jako element programu rozwoju instytucjonalnego, IBnGR, Warszawa.

Flejterski S., Panasiuk A., Perenc J., Rosa G., 2005, Współczesna ekonomika usług, Wydawnictwo Naukowe PWN, Warszawa.

Hantyszyn-Dzikowska A., Polcyn J., 2015, Regionalne zróżnicowanie dostarczania usług publicznych - wybrane aspekty metodologiczne, [w:] J. Polcyn, P. Głowski (red.), Rozwój regionalny i jego determinanty, t. II, Wydawnictwo Państwowej Wyższej Szkoły Zawodowej im. Stanisława Staszica w Pile, Piła, s 249-267.

Heffner K., 2002, Czynniki osadnicze wpływajqce na potencjał rozwojowy obszarów wiejskich, [w:] A. Rosner (red.), Wiejskie obszary kumulacji barier rozwojowych, IRWiR PAN, Warszawa, s. 75-106.

Heffner K., 2010, Regiony międzymetropolitalne a efekty polityki spójności w Polsce, [w:] M. Klamut, E. Szostak (red.), Jaka polityka spójności po roku 2013?, Wyd. Uniwersytetu Ekonomicznego we Wrocławiu, Wrocław, s. 163-184;

Heffner K., 2011a, Regionalny wymiar dychotomii rozwoju obszarów wiejskich, [w:] W. Kamińska i K. Heffner (red.), Dychotomiczny rozwój obszarów wiejskich? Czynniki progresji, czynniki peryferyzacji, Studia KPZK PAN, 138, Warszawa, s. 9-34.

Heffner K., 2011b, Wieś jako przedmiot badań w gospodarce przestrzennej. Procesy zagospodarowania przestrzeni wiejskiej w Polsce, [w:] M. Halamska, (red.), Wieś jako przedmiot badań naukowych na poczq̨tku XXI wieku, Wyd. Naukowe Scholar, Warszawa, s. 49-72.

Heffner K., Gibas P., 2013, Delimitacja przestrzenna obszarów wiejskich o słabym dostępie do usług publicznych w województwie lubuskim, Ekspertyza dla Urzędu Marszałkowskiego Województwa Lubuskiego, Zielona Góra.

Heffner K., Gibas P., 2015, Obszary funkcjonalne i ich zwiq̨zki z zasięgiem oddziaływania ośrodków subregionalnych (na przykładzie województwa opolskiego), Studia Miejskie 18, Wyd. Uniwersytetu Opolskiego, Opole, s. 9-24.

Heffner K., Klemens B., 2012. Warunki życia i aktywność społeczno-gospodarcza mieszkańców na obszarach wiejskich (na przykładzie województwa opolskiego), Barometr Regionalny, 4 (30), Wyższa Szkoła Zarządzania i Administracji w Zamościu, s. 81-88.

Heffner K., Klemens B., 2013, Koncepcje zmian i nowe procesy przestrzenne na obszarach wiejskich w Polsce, [w:] S. Korenik, A. Mempel-Śnieżyk (red.), Kryzys finansowy a programowanie rozwoju jednostek przestrzennych, Uniwersytet Ekonomiczny we Wrocławiu, Wrocław, s. 90-101.

Heffner K., Klemens B., 2015, Wiejskie obszary funkcjonalne w kontekście dostępu do usług publicznych (na przykładzie województwa opolskiego), Studia Obszarów Wiejskich, 38, s. 51-70.

Kachniarz M., 2007, Efekt skali a efektywność usług publicznych, Katedra Gospodarki Przestrzennej, Uniwersytet Ekonomiczny, Wrocław. 
Kachniarz M., 2012, Efektywność usług publicznych - teoria i praktyka, Wydawnictwo Uniwersytetu Ekonomicznego we Wrocławiu, Wrocław.

Kamruzzaman M., Hine J.,. 2011, Participation index: A measure to identify rural transport disadvantage? Journal of Transport Geography, 19, s. 882-899.

Kijowski D., Misiąg W., Prutis S., Stec M., Szlachta J., Zaleski J., 2004, Wprowadzenie do programu rozwoju instytucjonalnego, Instytut Badań nad Gospodarką Rynkową, MSWiA, Warszawa.

Klemens B., 2013, Dostęp do usług publicznych na obszarach wiejskich województwa opolskiego, [w:] S. Korenik, A. Mempel-Śnieżyk (red.), Kryzys finansowy a programowanie rozwoju jednostek przestrzennych, Uniwersytet Ekonomiczny we Wrocławiu, Wrocław, s. 151-163.

Kłodziński M., 2005, Dywersyfikacja gospodarki wiejskiej, [w:] A. Rosner (red.), Uwarunkowania i kierunki przemian społeczno-gospodarczych na obszarach wiejskich, IRWiR PAN, Warszawa, s. $29-40$.

Kobylińska U., 2013, Mierniki sprawności usług publicznych, Współczesne Zarządzanie, 2, s. 131-140.

Komornicki T., Śleszyński P., Rosik P., Pomianowski W., 2009, Dostępność przestrzenna jako przesłanka kształtowania polskiej polityki transportowej, Biuletyn KPZK PAN, 241, Warszawa.

Kożuch B., Kożuch A., 2011, Istota współczesnych usług publicznych, [w:] B. Kożuch, A. Kożuch (red.), Usługi publiczne. Organizacja i zarządzanie, Monografie i Studia Instytutu Spraw Publicznych Uniwersytetu Jagiellońskiego, Kraków, s. 37-45.

Kuźnik F. (red.), 2013, Efektywne świadczenie miejskich usług publicznych. Analiza - zarzqdzanie - polityka, Wydawnictwo Uniwersytetu Ekonomicznego w Katowicach, Katowice.

Malik K., Bedrunka K., 2015, Efektywność strategiczna i alokacyjna polityki rozwoju regionu [w:] M. Markowska, D. Głuszczyk, A. Sztando (red.), Problemy rozwoju regionalnego i lokalnego, Prace Naukowe UE we Wrocławiu, 393, Wrocław, s. 45-52.

Michalska-żyła A., 2016, Jakość życia na poziomie lokalnym, Acta Universitatis Lodziensis, Folia Sociologica, 56, s. 53-66.

Monitorowanie usług publicznych w miastach. Analiza porównawcza: kultura, ochrona zdrowia, pomoc społeczna, transport, 1999, Związek Miast Polskich, Poznań.

OECD 2009, OECD Territorial Reviews: Poland 2008 (Polish version), 2009, OECD Publishing, Mininisterstwo Rozwoju Regionalnego, Paris.

OECD 2010, Strategies to Improve Rural Service Delivery, OECD Publishing, Paris. DOI: http://dx.doi.org/10.1787/9789264083967-en.

Polska 2030. Trzecia fala nowoczesności, 2011, Ministerstwo Rozwoju Regionalnego, Warszawa.

Program Rozwoju Obszarów Wiejskich na lata 2014-2020, 2014, Ministerstwo Rolnictwa i Rozwoju Wsi, Warszawa.

Przygodzka R., 2010, Usługi publiczne a jakość życia w regionach peryferyjnych, [w:] A. Noworól (red.), Jakość życia a procesy zarzqdzania rozwojem i funkcjonowaniem organizacji publicznych, tom II, Monografie i Studia Instytutu Spraw Publicznych UJ, Kraków, s. 205-221.

Shergold I., Parkhurst G., 2010, Operationalising "sustainable mobility": The case of transport policy for older citizens in rural areas, Journal of Transport Geography, 18, s. 336-339.

Sołtys J., 2013, Usługi publiczne jako czynnik miastotwórczy i zyancznik rangi miasta w sieci osadnicznej na przykładzie małych miast Polski północnej, Acta Universitatis Lodziensis. Folia Geographica Socio-Oeconomica, 15, s. 3-19.

Strzelecki Z., Gałązka A., Jastrzębska E., Legutko-Kobus P., 2013, Raport problemowy: Dostępność usług publicznych i ich efektywność ekonomiczna, na potrzeby realizacji projektu Usługi publiczne w powiecie płockim - zmiany dla teraźniejszości i przyszłości, Warszawa. 
Szarfenberg R., 2010, Jakość usług pomocy społecznej. Problemy Polityki Społecznej, Studia i Dyskusje, 13, s. 41-57.

Śleszyński P., 2014, Dostępność czasowa i jej zastosowania, Przegląd Geograficzny, 86, 2, s. 171-213. The New Rural Paradigm: Policies and Governance, OECD, Paris, 2006.

Velaga N.R., Nelson J.D., Wright S.D., Farrington J.H., 2012, The Potential Role of Flexible Transport Services in Enhancing Rural Public Transport Provision, Journal of Public Transportation, 15, 1, s. 111-131.

Wańkowicz W., 2004, Wskaźniki realizacji usług publicznych, Program Rozwoju Instytucjonalnego, Małopolska Szkoła Administracji Publicznej Akademii Ekonomicznej w Krakowie, Kraków.

Wolf S., 2007, Does Aid Improve Public Service Delivery?, Review of World Economics, 143 (4), s. 650-672.

Zawicki M., Mazur S. (red.), 2004, Analiza instytucjonalna starostwa powiatowego. Przewodnik dla samorzq̨ów, Małopolska Szkoła Administracji Publicznej Akademii Ekonomicznej w Krakowie.

\section{Summary}

The article presents exemplary research on the availability and quality of public services. Moreover, it discusses the categories of public services and various examples of services, referring them especially to the local level (particularly in rural areas). The focus is put mainly on the public services of social, administrative and technical character. The article discusses the effects of public services' low level and the importance of enhancing their quality in rural areas. Presented considerations are conducted primarily based on the analysis of qualitative and quantitative data collected in rural areas located in the Opolskie Voivodship. 
http://rcin.org.pl 